\title{
Ons belydenis: Grieks of Kosher?
}

\author{
L.F. Schulze \\ Departement Dogmatologie en Ekklesiologie \\ Potchefstroomse Universiteit vir $\mathrm{CHO}$ \\ POTCHEFSTROOM
}

\begin{abstract}
Our confession: Greek or Kosher?

Since the rise of liberal theology the Hellenization of Christian dogma has been stated over and over again. The thesis was first propounded by Schleiermacher, and the cue was taken up by Harmack. An echo of the thesis was heard in the works of the fathers of modern Calvinist philosophy, though with marked differences between Vollenhoven and Dooyeweerd. Two to three decades ago the (supposed) fact of the Hellenization of Christian dogma was reversed into an antiGreek slogan by liberation theologians: We must think in the Jewish mode (i.e. monist, functional, concrete) instead of the Greek mode (dualist, static, abstract)! This simplistic slogan is coumtered by the question: If there were in New Testament times Palestinian Jews and Hellenistic Jews, what then, is the "Jewish" mode of though?

Is our confession, however, really a distortion of biblical doctrine? In an attempt to answer this question the First Article of the Apostolicum and the definition of hypostasis in the Nicaean Creed are used as illummating examples. Finally, it is argued that history has shown us two clear examples of Hellenization of Christianity in the systems of Dionysius the Areopagite and of Marsilio Ficino's "Platonic Academy" of Florence.
\end{abstract}

\section{Die probleem}

Sedert die opkoms van die liberale teologie sowat twee eeue gelede hoor ons in alle toonaarde die wysie van "Die vergrieksing van die teologie". Party sing die wysie meer gedrae in die bas op die woorde "Die Kerkvaders en die konfessies" (bv. Harnack, 1931:3). Ander sing fortissimo in die sopraan: "Die Nuwe Testament is Grieks, is Platonies-dualisties, leer die dualisme van tydelik-ewig, sienlik-onsienlik, verbygaande-blywend" (bv. Hebr. 8:5; 9:23-24). Dit is uiteraard onmoontlik om al die woordvariasies op die wysie van "vergrieksing" hier weer te gee. Met enkele voorbeelde word volstaan.

Schleiermacher (1768-1834) was en is - ten spyte van Karl Barth (1886-1968) se heftige protes - nog steeds die leidende ster van die moderne teologie. Binne die raamwerk van sy oortuiging dat die godsdiens in die religieuse aflanklikheidsgevoel van die mens setel, het die rasioneel-abstrakte fonmulering van dogmas nie lekker ingepas nie. Daarom stel hy die (vir hom) vreemde ontwikkeling van 
gevoel $n a$ rede aan die kaak as 'n vergrieksing van die evangelie. Bray (1984:18) stel dit só:

Schleiermacher maintained that the pure teaching of Jesus had been corrupted by Greek philosophy and Roman legalism, which between them had produced the great theological systems of classical orthodoxy.

Hoe dit gebeur het en watter faktore in die vergrieksing van die leer van Jesus 'n rol gespeel het, is deur Schleiermacher se dissipels nagevors. Twee van sy deurlugtige navolgers se name is werd om hier genoem te word: August Neander (1789-1850), een van die bouers aan kerkgeskiedenis as aparte teologiese vak, en Adolf Harnack (1851-1930), vader van die vak dogmageskiedenis. Die eggo van Schleiermacher word duidelik gehoor in die eerste hoofstuk van deel 2 van Harnack se dogmageskiedenis (Eng. vertaling in Bray, 1984:19):

How great the innovations actually were, however, may be measured by the fact that they signified a scholastic tutelage of the faith of the individual Christian, and restricted the inmediateness of religious feelings and ideas to the narrowest limits ... The fixing of the tradition under the title apostolic necessarily led to the assumption that whoever held the apostolic doctrine was also essentially a Christian in the apostolic sense.

Hoe diep die gedagte van vergrieksing van die Christelike leer in die moderne teologie ingeburger is, is uit bostaande duidelik: die moderne teologiese vakke Kerkgeskiedenis en Dogmageskiedenis is vanuit die staanspoor hierop gebou. Op hierdie spoor word tot vandag voortgegaan. Die titel van die kerkhistorikus Walter Bauer (oorl. 1960) se boek, Rechtgläubigkeit und Ketzerei im allesten Christentum, sê méér as wat vermoed word. Strecker som in sy voorwoord tot die tweede uitgawe (Bauer, 1964:v) van die boek Bauer se standpunt in 'n enkele sin op:

Rechtgläubigkeit und Ketzerei verhalten sich im altesten Christentum nicht wie Primäres und Sekundäres zueinander, sondern die Häresie ist in zahlreichen Gebieten die ursprüngliche Repräsentanz des Christentums. Walter Bauer hat diese These in dem vorliegenden Werk konsequent durchgefürht ...

Bauer het met sy werk ons in die tipiese multi-sfeer van ons relativistiese eeu (multi-kultureel, multi-etnies, ens.) tuisgebring. Bauer se siening van 'n meervoudigheid van religieuse opvattings in die Nuwe Testament is entoesiasties deur 'n Nieu-Testamentikus soos James Dunn (geb. 1939) in sy Unity and Diversity in the New Testament (1977/1990) opgeneem. In sy voorwoord (Dunn, 1991:xi) erken hy die stimilus van Bauer:

The book has several purposes First, it seeks to explore the issues raised by Baver with reference to the NT. Can we properly speak of "orthodoxy and 
heresy in earliest Christianity'? What is 'the unity of the NT'? How broad is the diversity within the NT?

Vanuit 'n heel ander hoek het daar in Nederland in die dertigerjare die Calvinistiese Wysbegeerte van die Wetsidee gestalte begin kry. In aansluiting by A. Kuyper het Vollenhoven en Dooyeweerd kostelike insigte na vore gebring, waaronder dié van die moderne filosofie as gedra deur die dialektiek van natuur en vryheid nog steeds hoogs aktueel is (kyk bv. Dooyeweerd, 1949:37-41). Vollenhoven en Dooyeweerd het die tema van die vergrieksing van die Christendom in 'n skolastieke sintese vanuit húlle visie opnuut na vore gebring Wat tans hier ter sake is, is bloot die opmerking dat hulle onderling oor die kardinale kwessie van die periodisering van die proses van vergrieksing verskil het. Dooyeweerd (1949:35) meen dat die Christelike grondmotief tot by Augustinus (354-430) "in het algemeen zuiver gehandhaafd" is - ook al het Augustinus reeds die later belaste terne natuur en genade gebruik (Dooyeweerd, 1949:35; verw. 14a). Op sy beurt dateer Vollenhoven (1950:19) die opkoms en bloei van die sintese-filosofie as "de eeuwen tusschen omstreeks 40 na $\mathrm{Chr}$ en het late Humanisme". Hierdie verskil in datering is loodswaar van implikasies. Blóót op grond van dié verskil kan byvoorbeeld gevra word: a) het die Nuwe Testament sèlf, wat omstreeks 40 n.C. nog nie bestaan het nie, deel aan die sintese of nie, en b) was daar ooit 'n "suiwer Christendom"?

Sedert sowat drie dekades gelede het die bevrydingsteoloë ' $n$ ander kinkel in die kabel begin aanbring deur hartstogtelik te probeer om (tipies dialekties) in naam van die "toekoms" die historiese ontwikkeling van die verlede in trurat te gooi: "ons moet leer om Joods te dink en van die Griekse denke gespeen raak"! Op die oog af lyk dit asof die kloof wat Marcion (2de eeu) tussen Ou en Nuwe Testament aangebring het, deur bevrydingsteoloë nuwe lewe ingeblaas word. Dis egter 'n halwe waarheid. Seker, die dualisıne tussen Ou en Nuwe Testament word gehandliaaf maar terselfdertyd word Marcion se kettery op sy kop gedraai. Laasgenoemde wou van die Ou Testament met sy demiurg-skepper van die stoflike wêreld, en daarmee van die "Joodse denke" ontslae raak. Die bevrydingsteoloë wil egter van die Nuwe Testament met sy "Griekse denke" ontslae raak, want vir die bevrydingsteoloë gaan godsdiens om die mens en sy wêreld, hier en nou, en die Ou Testament leer ons juis om aards, konkreet en dinamies in terme van "hier en nou" te dink. Die "Griekse denke" van die Nuwe Testament, so meen hulle, is egter hemels, abstrak en staties. Dáármee kan die mens met sy dwingende materiële behoeftes niks uitrig nie (vgl. Meijering, 1974:7-12 en 1974:92, verw. 1-6 vir Nederlandse literatuur). Bowendien is die Griekse denke óók nog deterministies (Wiersinga, 1972:21, 30; Moltmann, 1974:230, 253; Solle, 1975:26; Nicol, 1992; Kömg, 1992). 


\section{Afbakening}

Die kardinale vraag in die lig van bostaande probleem (pt.1) is: Is die Christelike belydenis vergrieks? Dié vraag impliseer ' $\mathrm{n}$ menigte ander vrae, waaronder: Is die kerk as volk van God besig met selfmisleiding wanneer die Apostoliese Geloofsbelydenis Sondae as samevatting van die Bybelse waarheid in "die eenheid van die geloof' opgesê word? Word (onbewustelik) 'n vreemde God aangehang en 'n verdraaide evangelie as waarheid omhels en verkondig?

In hierdie onoorsigtelike mynveld word net 'n paar versigtige treë gewaag om op bogenoemde kardinale vraag ' $n$ antwoord te probeer gee.

Eerstens word die Apostolicum se Eerste Artikel teen die heersende omstandighede belig. Tweedens word enkele opmerkings oor die betekenis van "vergrieksing" gemaak. Ten slotte word enkele voorbeelde aangehaal om aan te toon hoe "vergrieksing" regtig lyk.

\section{Beredenering}

\subsection{Die Eerste Artikel in 'n Hellenistiese wêreld}

God se openbaring in Jesus Christus het nie in 'n tydlose lugleegte plaasgevind nie: Hy het in ons aardse, menslike geskiedenis verskyn. Die Skrif sê dat sy geboorte in Betlehem die vervulling van Miga se profesie was (Matt. 2:5-6); dat Josef en Maria na Betlehem moes gaan omdat keiser Augustus 'n sensus aangekondig het in die tyd toe Cirénius goewemeur van Sirië was (Luk. 2:1-7). Kultuur-histories word hierdie tyd as Hellenisme aangedui - 'n tyd waarin die Griekse taal en kultuur die destyds beskaafde wêreld (na Alexander se segetog) oorheers het, terwyl die Romeine gaandeweg die politieke mag verkry het. Die Nuwe Testament, gerig op die destydse wêreld, is dan ook in Grieks geskryf.

Hellenisme is moeilik definieerbaar omdat verskillende skrywers dit of in enger of in wyer sin verstaan en gevolglik ook verskillend dateer. Bowendien word die begrip self in verskillende betekenisse gebruik. Soms word dit gebruik as aanduiding van die periode van uitbreiding van die Griekse taal en kultuur in die Ooste (deur Alexander die Grote), wat slegs 'n gedééltelike (politieke en religieuse) kultuurversmelting tot gevolg gehad het. Andersyds word dit gebruik as blote aanduiding van die Griekse kultuur. Die Duitsers het 'n voorliefde om Hellenismus (sedert J.G. Droysen, 1836) in eersgenoemde sin te gebruik, terwyl Engelse en Franse literatuur dit in laasgenoemde sin besig (Anon., 1973:679). Hierdie meersinnigheid van die begrip moet by bronnestudie in gedagte gehou word. In hierdie artikel word die term meer in Duitse sin gebruik om die invloed van die Griekse taal (koinê) en kultuur op die destyds beskaafde wêreld aan te dui. Tiperend van hierdie wêreld was sy kosmopolitiese aard, soos uitgedruk in die wêreldbroederskap van die Stoa, én sy heilsindividualisme, soos dit in die 
misterie-godsdienste tot uiting kom. Laasgenoemde aspek is hier van belang omdat heilsindividualisme dikwels met askese gepaard gaan, soos duidelik in die Oosterse godsdienste gesien word. In die Christendom was askese die wortel waaruit die latere Roomse Maria-verering ontspring het.

Askese se oorsprong lê in sekere gnostieke kringe. Sover bekend was die Protoevangelie van Jakobus (2de helfte van die 2 de eeu) die eerste bron wat die permanente maagdelikheid van Maria vermeld. Die gedagte dat die broers van Jesus uit 'n vorige huwelik van Josef gebore is, het spoedig in kerklike kringe ingang gevind. Hiëronimus (347-419), wat 15 jaar lank in sy klooster in Betlehem aan die Editio vulgata gewerk het, het die teorie oor Jesus se "broers" verander: hulle was in werklikheid sy neefs, want Josef self het hom nooit aan huweliksverkeer skuldig gemaak nie (Lohse, 1966:200). Dis vir Protestante haas onvoorstelbaar watter prominente plek askese, en dan veral in die sin van seksuele onthouding, in die fantasie, denke en lewenspraktyk van die Christene van die 4de en 5de eeue ingeneem het. Daar is kwalik 'n Kerkvader wat nie 'n De virginitate geskryf het nie (Harnack, 1931:10), en hierdie asketiese afkeer van die stoflik-liggaamlike kom in die eminente Augustinus se sondeleer as concupiscentia duidelik na vore (Lohse, 1966:113-114). Waarskynlik moet die eer om die asketiese ideaal die duidelikste te formuleer aan die beroemde biskop van Milaan, Ambrosius (334-397), gegee word. In De virginibus (1,3 e.v.) betoog hy dat die éintlike núwe wat die Clristelike godsdiens gebring het, die leer van die maagdelikheid is. Maagdelikheid is die spesifiek Christelike deug, die moeder en samevatting van alle etiese voortreflikhede (gesiteer deur Harnack, 1931:10-11, verw.1).

Op die vraag waar hierdie evident onbybelse opvatting vandaan kom, sou dit simplisties wees om die dualisme van stof-gees van die Griekse filosofie as eerste en enigste sondebok te noem. Die filosowe was immers 'n elite-groep en gesteld op hulle "apartheid" van die massa, waaronder die oorgrote meerderheid Christene getel het (Anon., 1973:681; Bray, 1984:89). Die invloed van die Gnostiek en van die populêre misteriegodsdienste moet by die opkoms van die askese ook - en waarskynlik vóór ander faktore - in berekening gebring word. Daarby moet in gedagte gehou word dat askese lank voor die Christelike jaartelling reeds bekend was. Daarvan getuig die monnikekloosters van Tibet en Japan, die "nonne" van die Skandinawiese lande (die priesteresse van Freya), die maagde van ou Atene en Rome (kyk Hislop, 1959:223).

Hoe dit ook al sy, wanneer die skering en inslag van die askese in die 4de en 5 de eeue in ag geneem word, sou 'n mens geneig wees om Marcion as profeet van die komende kerklike ontwikkeling en belydenisvorming aan te sien. En tog ... só 'n siening is - téén alle verwagting in - verkeerd die kerk het nié Marcion se verskraalde kanon vir sy rekening geneem nie en in die dampkring van die 4 de- 
eeuse asketisme tóg sy geloof in God, die Skepper van hemel en aarde, van alle sienlike en onsienlike dinge, geformuleer (Kons. van Konstantinopel, 381, bevestig te Chalcedon, 451). Waarskynlik in dieselfde tyd is die woorde "Skepper van hemel en aarde" aan die Eerste Artikel van die Apostoliese Belydenis toegevoeg.

Samevattend kan twee afleidings uit bostaande gegewens gemaak word. Eerstens: dit lyk nie moontlik om die belydenisvorming afdoende uit die sosiohistoriese omstandighede van die tyd te verklaar nie. Tweedens: dit blyk dat die belydenisvorming, ten spyte van die uitsprake van invloedryke Kerkvaders (Ambrosius, Hiëronimus, Augustinus), tog sy eie (geheimnisvolle) weg gegaan het.

\subsection{Wat beteken "vergrieksing"?}

Hierdie veelkantige vraag moet versigtig benader word. Bepaalde pikante terme, soos deutero-Jesaja, Christusgebeure, Jahwis, Elohis, interteks, implisiete leser, ensovoorts, kan, mits hulle sonder nadere definiëring oorgeneem word, aandui dat 'n gereformeerde teoloog wat dié tenne gebruik, die inhoud van die betrokke literêre, filosofiese of teologiese beskouing sy eie mak. Aan die ander kant word die meerderheid terme in algemene omloop se betekenisnuanseringe bepaal deur die konteks waarin hulle gebruik word.

In die lig van bogenoemde opmerkings lyk dit sinvol om by die beantwoording van die vraag na "vergrieksing" 'n leksikale en 'n inhoudelike vlak te onderskei (vgl. Bray, 1984:84). Om binne perke te bly, word die aandag hoofsaaklik aan eersgenoemde aspek gegee. Terwyl hierdie artikel op die "Hellenisering" van die belydenis toegespits is, moet daar tog 'n paar opmerkings oor die Nuwe Testament sélf gemaak word. Dit hou in dat die leksikale aspek in drie fasette beskou word: a) die Grieks van die Nuwe Testament; b) die gebruik van onbybelse woorde in die belydenis, c) die behoefte om te midde van verwarring, sekere (filosofiese) terme, soos Luther tereg opgemerk het, te "doop".

\subsubsection{Die Grieks van die Nuwe Testament}

Is die blote gebruik van Griekse woorde reeds 'n bewys van "vergrieksing"? Om bostaande vraag bevestigend te beantwoord sou beteken dat die feit dat die Nuwe Testament in Grieks geskryf is, reeds sy "Hellenisering" bewys. Só 'n opvatting sou egter onrealisties en vergesog wees. Selfs kritiese voorstanders van die "vergrieksing" van die Nuwe Testament erken gewoonlik náás die JoodsHellenistiese (Paulus, Hebreërs) en heidens-Hellenistiese (Johannes) tradisies nog 'n Joods-Palestynse tradisie (Jesus, Petrus, Jakobus, Judas) in die vorming van die Nuwe Testament (vgl. Bray, 1984:56). Bowendien weet elke nugter leser van 'n Duitse artikel dat die feit dat dit in Duits is, nog nie Kant se invloed weerspieël 
nie - ook al word tipiese terme soos Rede, Kritik, Sollen ensovoorts gebruik. Alles hang af van die verband waarin hierdie terme gebruik word. Dieselde geld van die derduisende woorde van die Nuwe Testament - ook woorde soos logos, hypostasis en ousia - wat in die Hellenistiese wêreld van destyds gebruik is. Runia toon in sy omvattende studie van die stand van navorsing in verband met Filo se invloed op die Nuwe Testament (en Kerkvaders) aan dat, ten spyte van parallelle tussen Filo enersyds en Johannes, Paulus en Hebreèrs andersyds, die Nuwe Testament se afhanklikheid van die Platoniese Filo nog lank nie "bewys" is nie. Die rede: die konteks waarin Filo skryf en dié van die Nuwe Testament is telkens ingrypend verskillend (Runia, 1993:63-86).

\subsubsection{Onbybelse woorde}

Die gebruik van "onbybelse" woorde in die vorming van die belydenis is ooglopend en vir sommige kontensieus. Dit raak woorde soos trias (Lat.: trinitas) en homoousios. Die leksikale argument teen "mensgemaakte woorde" is sedert die 4de eeu in swang, toe die Ariane heftig beswaar gemaak het teen die gebruik van sulke onbybelse terme. Tydens die Reformasie het die argument weer opgeduik. Tans word dit nog algemeen gebruik deur teoloë wat dogma (konfessie) en dogmatiek in diskrediet probeer bring (Bray, 1984:86).

Calvyn het egter reeds 'n nugter oordeel oor die saak gegee. Hy sê dat die kerk eie woorde spaarsaam kan gebruik mits dit "eerbiedig en woordgetrou die waarheid van die Skrif self dien" (Inst. 1.13.3). Calvyn merk verder op dat die kerk in die 4de eeu gedwing was om onbybelse woorde te gebruik ten einde die ketters uit hulle skuilhoeke "uit te boender" (Inst. 1.13.4).

\subsubsection{Hypostasis word "gedoop"}

Dit is uit die dogmageskiedenis duidelik dat daar sedert die begin van die $3 \mathrm{de}$ eeu aanvanklik verwarring in die teologiese ontwikkeling in verband met die betekenis van bepaalde woorde geheers het. Hierdie verwarring was deel van die voorspel waaruit ten slotte tog 'n eenstemmige dogmatiese formulering uitgekristalliseer het. 'n Voorbeeld hiervan is die verskillende gebruik van hypostasis.

Naas die betekenis van vertroue ( 2 Kor. 9:4; Heb. 3:14) - eintlik: die grond wat die vertroue wek (Louw \& Nida, 1988:376) - word die woord een maal in die sin van wese, essensie, natuur in Hebreèrs 1:3 gebruik (Louw \& Nida, 1988:586)

Origenes (185-254), die beroemde teoloog van Alexandriè, dui die drieheid van Vader, Seun en Heilige Gees as hypostases in die gemeenskaplike goddelike natuur aan (Lohse, 1966:46; Wolfsoll, 1976:318-319, 322; Bray, 1984:84). Ondertussen het Tertullianus (ong. 160-220) dié betrokke Griekse woord in Latyn met substantia vertaal as aanduiding van die één goddelike Wese (Lohse, 
1966:45; Wolfson, 1976:325). Dieselde woord word dus gebruik om sowel die drieheid as die eenheid aan te dui! Hierdie weersprekende gebruik van dieselfde term het groot verwarring in die kerk veroorsaak. En tog sê Bray (1984:84) tereg:

... each meaning is legitimate in its own context. Hypostasis refers in the first instance to an objective reality which can be perceived by the intellect. When Tertullian thought of God, he thought of the One Being, and therefore, for him, this objective reality was singular. When Origen thought of God, he saw three Beings, each of whom shared the same nature. Thus, for him, the objective reality was threefold. One word, with one 'meaning', therefore came to be used in two potentially contradictory senses!

Die kerk het hierdie plofbare toestand nie sonder misverstand en verdagmakery opgelos nie. Toe Origenes se Griekssprekende volgelinge van Tertullianus se opvattings hoor, was hulle verontwaardig, te meer nog toe hulle verneem dat die drieheid met die Latynse woord persona weergegee word. Persona was in Grieks prosoopon, wat masker beteken. Daaruit kon die gedagte ontstaan dat God nie werklik drie-enig is nie maar die Een wat in sy werke, soos één toneelspeler in verskillende rolle, net telkens ' $n$ ander masker opsit. Sabellius (begin 3de eeu) het inderdaad hierdie pad van "modalisme" geloop en geleer dat die Vader aan die kruis gesterf het (patripassianisme). Dat die gebruik van persona in die sin van "masker" nooit die bedoeling van Tertullianus was nie, blyk daaruit dat sy hoofwerk teen Sabellius se geesgenoot, Praxeas, gerig was. Ten slotte was dit Basilius die Grote (329-379) wat die verwarring sou opklaar met sy insig dat persona nie masker is nie maar hypostasis, dit is: selfstandige bestaan. Daarmee het hy Oos en Wes weer teologies verenig.

Die vrede het egter nie lank geduur nie. Hiëronimus, wat altyd 'n oog vir skandaal gehad het, kla in 'n brief aan die biskop van Rome, Damasus (366-384), dat die Grieke van drie substansies in God praat. Daarmee beskuldig hy hulle in werklikheid van triteissme, die diens van drie gode. Calvyn, wat die werke van die Kerkvaders volledig bestudeer het, ontmasker die dwase argument van Hiëronimus (Inst. 1.13.5, in die pittige vertaling van Beveridge):

... how greatly is Jerome perplexed with the word Hypostasis! He suspects some lurking poison, when it is said that there are three Hypostases in God. And he does not disguise his belief that the expression, though used in a pious sense, is improper; if, indeed, he was sincere in saying this, and did not rather designedly endeavour, by an unfounded calumny, to throw odium on the Eastern bishops whom he hated. He certainly shows little candour in asserting that in all heathen schools ousia is equivalent to Hypostasis - an assertion completely refuted by ... common use. 
Wat nodig was om die verwarring tussen Griekse en Latynse Kerkvaders op te klaar was die insig om te onderskei tussen "twee vlakke" van objektiewe realiteit in God (Bray, 1984:86), naamlik die één Wese én die drie Persone. Aan die een kant moes die Persone nie met die Wese verwar of daarin opgelos word nie (modalisme), want die Persone het 'n eie, werklike bestaan. Aan die ander kant mog die Wese nie in drie verdeel en in die Persone opgelos word nie, want dit sou triteïsme impliseer. Of, om dit in die woorde van die (latere) Belydenis van Athanasius (art. 3) te sê: daar moes geleer word om "die een God in die Drieheid en die Drieheid in die Eenheid" te onderskei en te eer - "sonder om die persone te vermeng of die wese te deel" (art. 4). Bray (1984:86) som die situasie soos volg op:

Some means therefore had to be found by which the plurality in the unity could be expressed without losing the underlying validity of either concept. In trying to do this, the Fathers of the Church were forced to define hypostasis in a way which is without parallel in ancient philosophy yet does not do violence to the semantic range of the word in the Greek language (my kursivering - LFS).

Om bostaande belangrike uitspraak van Bray toe te lig kan daarop gewys word dat ouer filosowe (w.o. Aristoteles) inderdaad hypostasis ("onder-staande", Lat.: sub-stare, substantia) en ousia (wese) sinoniem gebruik het (Wolfson, 1976:317318; Bettenson, 1975:32-33). In die belydenisvorming is daar egter ten slotte duidelik tussen die twee begrippe onderskei. Hierdie onderskeiding het erfgoed van die Christendom geword, sodat Calvyn (Inst. 1.13.6) die volgende omskrywing kon gee:

'Persoon' noem ek dus die selfstandigheid in die Wese van God wat in verhouding tot die ander met 'n onmeedeelbare eienskap onderskei word. Onder die woord selfstandigheid wil ons dan iets anders as 'wese' verstaan. ${ }^{1}$

Wanneer die aanvanklike terminologiese verwarring opsommend in sy breer historiese raamwerk beskou word, word dit duidelik dat die hele kwessie van "vergrieksing" meer gekompliseerd is as wat algemeen daarvan gemaak word. Minstens drie aspekte van die probleem moet onderskei word:

1 Dit is jammer dat Taljaard in sy vastc cortuiging van 'n vroek "sintese-denke" in dic Christendom hicrdic belangrike onderskeiding miskyk. Sonder om Athanasius se standpunt eers te omskryf, val Taljaard (1995:231-232) weg om hom met Augustinus te kontrasteer "Anders as Athanasius gebruik Augustinus vir sy Trinitcitsleer die terme hypostasis en ousia in presies die teenoorgestelde sin: ousia dui die gemoenskaplike wese en hypostasis die persoonlike aan God bestaan dus uit drie substansies in een wesc." Dit is duidelik dat Taljaard se afleiding in verband met Augustinus nic korrek is nie 
* Die invloed van die Griekse denke op die Kerkvaders: algemeen, soos in die asketisme aan die lig kom, en besonder, soos in Origenes se teologie (kyk vir lg. Runia, 1993:157-183).

* Die vorming van die belydenis wat met gebruikmaking van Griekse terme tog 'n eie konnotasie daaraan gee en die Bybelse openbaring in eie taal wil weergee.

* Die tot dusver grootliks miskende betekenis van die heidense apologete se bydrae tot "vergrieksing". Bray (1984:87-89) gee hieraan aandag en toon aan hoe die aanvanklike veragting van die Platoniese owerhede vir die Christene (Plinius die jongere, Tacitus, Suetonius) met die optrede van Celsus verander: hy was die eerste heidense filosoof wat die Christendom ernstig beskou het. Om die Christene te kon bestry - só het Andresen in sy Logos und Nomos uitvoerig aangetoon - moes hy hulle beginsels sy eie maak. As Celsus se Ware Woord so vroeg as 130 n.C.gedateer moet word (Anon., 1957:133), dan was hy die eerste "sintese-filosoof"! Bray (1984:89) teken die situasie nog verder deur die hele ontwikkeling van die Neo-Platonisme daarin te betrek:

We cannot now reconstruct the course of events in detail, because our evidence is fragmentary; but it looks strongly as if Platonism was refashioned to meet the challenge of Christianity not the other way round. Christians may well have been influenced by the philosophical schools, but they remained on the offensive and gave far more than they got.

\section{Hoe lyk "vergrieksing" regtig?}

\subsection{Dionisius die pseudo-Areopagiet}

Hoe sou die Christendom gelyk het as dit voor die Platonisme en Neo-Platonisme gekapituleer het? Gelukkig is die antwoord op hierdie vraag bekend. Dit beteken: ons weet hoe die Christendom sou gelyk het as die Neo-Platonisme eenvoudig in 'n "sintese-denke" geabsorbeer is. Uit die geskiedenis is voorbeelde bekend, waarvan hier slegs twee kortliks aandag kry.

In 532 het 'n aantal Neo-Platoniese geskrifte onder die naam van Dionisius die Areopagiet verskyn en was waarskynlik uit Sirie afkomstig (Stumpf, 1975:160161). In sekere sin kan dié geskrifte as 'n laaste stuiptrekking van die heidendom beskou word, want toe die Christelike geloof in 380 die enigste wettige godsdiens in die Romeinse ryk geword het, is die filosofiese skole (vanwee hulle minimale invloed) nie verbied nie. Eers in 529 , tydens die regering van Justinianus, is dié skole gesluit. En dan: drie jaar later verskyn hierdie geskrifte, wat voorgee dat hulle uit die vroegste geskiedenis van die Christendom staın! Dit was 'n slim set, want Dionisius die Areopagiet was in die vroee kerk goed bekend. Daar was immers allerhande verhale oor hom in omloop. 
Vir ons is hy onbekend omdat die Bybel slegs 'n enkele keer (Hand. 17:34) sy naam noem. Al wat ons weet, is dat hy deur die prediking van Paulus in Atene tot bekering gekom het en dat hy lid van die Areopagus, dit wil sê, van die hoogste geregshof van Atene was. In die oë van die vroeë Christene het hy egter spoedig 'n belangrike man geword. Dionisius, biskop van Korinte (ong. 165173), meld dat Dionisius die Areopagiet die eerste biskop van Athene was. 'n Ander verhaal maak hom die stigter van die kerk in Parys (Grosheide, 1957:425). En as hierdie uitnemende bekeerling van Paulus Oor die hemelse hierrargie, Oor die kerklike hiërargie, Oor die Goddelike name en Oor die mistieke teologie geskryf en boonop nog tien briewe nagelaat het, moet dit gewig dra. Die geskrifte hét ook in die Middeleeuse teologie, veral in die opkoms van die Middeleeuse mistiek, 'n groot invloed gehad (Grosheide, 1957:425; Stumpf, 1975:161; Bray, 1984:90).

Die Neo-Platoniese aard van die geskrifte kan duidelik aangetoon word. Eerstens word die geskrifte gekenmerk deur 'n "negatiewe teologie": God is as hoogste wese onkenbaar, verhewe bo alle aardse teenstellings en gevolglik kan oor Hom net in ontkennings gepraat word - Hy is onkenbaar, oneindig, nie goed nie en nie sleg nie, nie groot nie en nie klein nie, en so meer. "To him (d.i. Dionisius) it was obvious that what characterized God was precisely that He did not have the attributes of finite creatures" (Stumpf, 1975:162). Agter hierdie opvatting van die absoluut verhewe God staan die gestalte van Plato, wat in sy Timaeus sê: "Dit is moeilik om die Skepper en Vader van hierdie Al te vind, en ook as jy Hom gevind het, dan is dit onmoontlik om Hom aan almal te verkondig" (in Meijering, 1974:22). Op grond van hierdie uitspraak het sommige Platoniste selfs gesê dat die Skepper nie die hoogste God is nie maar 'n laere God, en dat die hoogste God volslae onbekend is (Meijering, 1974:22). Tweedens is dit duidelik dat die geskrifte sterk aanleun teen die Neo-Platonis Proclus (ong. 410-485) se opvattings, veral sy "negatiewe kennisweg" (Grosheide, 1957:425; Stumpf, 1975: $161,162)$.

Die doel van die geskrifte vat Stumpf (1975:161) so saam: "The treatises of Pseudo-Dionysius attempt to relate Christian thought systematically with Neoplatonic philosophy", of, om dit in die tekenende taal van Bray (1984:90) te sê: "He wanted to convey Neoplatonism to an audience which would receive it only in Christian dress".

Die resultaat was 'n versameling mistieke geskrifte wat in die Middeleeue groot aansien sou geniet en selfs in sekere dele van Thomas van Aquino se teologie weerklank sou vind (Stumpf, 1975:162). Om alles te kroon, vind die snare wat Dionisius tokkel 'n duidelike eggo in sommige New Age-kringe van vandag.

Oor die inhoud van Dionisius se leer word slegs enkele opmerkings gemaak. 
God kan slegs geken word deur die mens wat die leer van die hemelse hièrargie opklim. Van een ervaring na die ander kom hy ten slotte tot kennis van die transfigurasie van ongeskape lig, dit is: die ekstatiese vereniging met God. (Die eggo hiervan: "Die stelling dat God lig is, is die letterlike WAARHEID. Deur die Lig, wat ook die Kennis genoem word, vind die openbaring van die Lewe plaas" [Holmes, 1988:19].) Wanneer die mens só 'n kortpad na God het, is 'n Versoener natuurlik nie meer nodig nie. Christus word slegs voorbeeld van die mistieke weg. Sy kruislyde was geen versoening nie maar 'n doding van die vlees wat die vlugtige verheerliking op die berg (Matt. 17:2) in die ewige glorie van die hemelvaart verander. (Die eggo: Holmes [1988:21] beroep haar ook op Matteus 17:2.) Die mistiek is ervaringsgodsdiens. Daarvoor is geen openbaring, geen leer, geen dogma nodig nie. Die rede hiervoor is eenvoudig: mistieke, ekstatiese ervaring is onuitspreeklik en kán nie in woorde, in "leer" geformuleer word nie. Waar die mistiek gebloei het, het die dogma nog altyd gekwyn - ook al sou mistici lippediens aan die belydenis verrig. Bray (1984:91) is heeltemal korrek as hy uit bostaande gegewens die volgende konklusie trek:

When Neoplatonism invaded the Church its effect was to stifle dogmatics, not to encourage confessional statements of an unblibical character. Yet even pseudo-Dionysius bears witness in his own way to the triumph of the gospel. Neoplatonism survived in the only way that it could - by being clothed in the garb of an alien religion.

\subsection{Die "Platoniese Akademie" van Florence}

Die geskiedenis het 'n nare manier om soms dieselfde draaie te maak. Hierdie feit word onder andere daarin gesien dat die ideale van Dionisius die pseudoAreopagiet byna duisend jaar later weer tydens die Renaissance in Noord-Italië sou opduik en 'n kortstondige bloei sou beleef. Die buitengewone intellektuele kunsgreep van Marsilio Ficino (1433-1499) met sy "Platoniese Akademie" teken Panofsky (1972:131) só:

But never before had an attempt been made to fuse Christian theology, fully developed as it was, with a great pagan philosophy, without impairing the individuality and completeness of either. The very title of Ficino's proudest work, Theologia Platonica, announces his ambition both to reintegrate the 'Platonic' system and to prove its 'full consonance' with Christianity.

Die woorde in aanhalingstekens kom uit 'n brief van Ficino aan aartsbiskop Giovanni Niccolo (Panofsky, 1972:131, verw. 4).

Om sy doel te bereik het Ficino drie geweldige take onderneem: Eerstens om deur middel van Latynse vertalings - met kommentaar - Plato en die Platonici, waaronder Plotinus, Proclus, Porphirius, Jamblichus en Dionisius die pseudoAreopagiet vir sy tyd toeganklik te maak. Tweedens om uit hierdie massale 
hoeveelheid gegewens 'n samehangende sisteem te skep wat nuwe lewe in die kulturele erfenis van sy eeu (van die mitologie tot die fisika, astrologie en mediese wetenskap) sou inblaas. Derdens om hierdie sisteem met die Christendom te harmonieer.

Dit is onmoontlik om hier 'n oorsig van Ficino se "Platoniese teologie" te gee daarvoor sou ' $n$ aparte artikel nodig wees (kyk die oorsig van Ficino se sisteem in Panofsky, 1972:130-144). Dit is genoeg om te sê dat Ficino, nes Dionisius die pseudo-Areopagiet (kyk Stumpf, 1975:161), 'n middeweg tussen die panteïsme van die Neo-Platonisme en die teïsme van die Christendom probeer vind het (Panofsky, 1972:131). Die hiërargie van meer na minder volmaakte wesens tussen God en kosmos én die aksent op die vita contemplativa met sy ekstase is in Ficino se opvattings teenwoordig (Panofsky, 1972:132, 140).

Die "Platoniese Akademie" van Florence het sy merk op sekere kunstenaars gelaat. Origens was sy bloei kortstondig. Daar was immers ander roeringe aan die kom: toe Ficino oorlede is, was Luther reeds 16 jaar oud.

Hierdie twee voorbeelde van konsekwente "sintese-denke" toon duidelik hoe die Christendom in vergriekse vorm sou gelyk het en dwing ons om die "vergrieksing" van die dogma met 'n knippie sout te neem.

\section{Bibliografie}

ANON 1957. Celsus. In Christelijke Encyclopedie, 2:133-134.

ANON 1973. Hellenisme. In Ensiklopedie van die Wêreld, 4:679-682

BAUER, W. 1964 Rechtglaubigkeit und Ketzerei im altesten Christentum Zweite Aufl. mit einem Nachtrag von G Strecker Tubingen : Mohr

BETTENSON, H. 1975. Documents of the Christian Church. 2nd ed, repr. London Oxford University Press.

BRAY, G 1984. Creeds, councils and Christ Leicester : Inter-Varsity

CALVIN, J 1962 Institutes of the Christian religion. Vol. 1. Transl. by H. Beveridge Grand Rapids : Eerdmans

CALVYN J. 1984. Institusie van die Christelike godsdiens. Bk. 1. Vert. deur H.W. Simpson Potchefstroom: CJBF

DOOYEWEERD, H 1949. Reformatie en scholastiek in de wijsbegeerte Bk 1. Franeker Wever

DUNN, J.DG. 1991. Unity and diversity in the New Testament 2nd ed., 2nd impr London SCM

GROSHEIDE, F W 1957. Dionysius de Areopagiet In Christelijke Encyclopedie, 2:425

HARNACK, A 1931 Lehrbuch der Dogmengeschichte Bd. 2. Fünte Aufl. Tübingen Mohr 
HISLOP, A. 1959. The two Babylons. 2nd American ed. Neptune, N.Y. : Loizeaux Brothers.

HOLMES, A. 1988. Vanwee die tyd ... Hogsback: Holmes

KÖNIG, A. 1992. God in beheer? Daar is uitsonderings. Beeld, 24 Nov.

LOHSE, B 1966. A short history of Christian doctrine. Transl. by F.E. Stoeffler. Philadelphia : Fortress Press.

LOUW, J.P. \& NIDA, E.A 1988. Greek-English lexicon of the New Testament, vol. 1. New York : UBS.

MEIJERING, E.P 1974. Onmodieuze theologie Kampen : Kok

MOLTMANN, J. 1974 The crucified God. Transl. by R A. Wilson and J. Bowden. London SCM.

NICOL, W 1992. Is God albeskikker? Sy beheer nog op pad om volle werklikheid te word Beeld, 27 Okt.

PANOFSKY, E. 1972. Studies in Iconology. Icon ed. New York : Harper \& Row

RUNIA, D.T. 1993. Philo in early Christian literature. A survey. Assen : Van Gorcum.

SOLLE, D 1975. Suffering. Transl. by E.R. Kalin. Philadelphia : Fortress

STUMPF, S.E. 1975. Socrates to Sartre. 2nd. ed New York: McGraw-Hill

TALJAARD, J.A L. 1995 ... en dit was aand, en dit word môre: Die sewende dag. Piet Retief : Veritas Persvereniging.

VOLLENHOVEN, D.H.Th. 1950. Geschiedenis der wijsbegeerte Bd 1. Franeker : Wever.

WIERSINGA, H 1972 Verzoening als verandering Baarn: Bosch \& Keuning.

WOLFSON, H.A. 1976 The philosophy of the Church Fathers Faith, trinity, incarnation 3rd ed., 2nd pr. Cambridge, Mass : Harvard University Press. 